\title{
Future Directions of Usable Science for Sustainable Rangelands: Water
}

\author{
By James P. Dobrowolski, and David M. Engle
}

\section{On the Ground}

- Usable science takes on a completely new meaning when you are looking to science to literally save your livelihood.

- The challenge for rangeland professionals, including research scientists, is accurately predicting the consequences to water of land-use change, climate change, and increasing competition for water while also providing socially acceptable science-based solutions.

- The good news for rangeland professionals and research scientists is that because water is indeed essential for life, our knowledge and skills will be essential for addressing these issues.

Keywords: water, usable science, research needs, water security, future research.

Rangelands 38(2):68-74

doi: $10.1016 /$ j.rala.2016.01.004

(C) 2016 The Society for Range Management

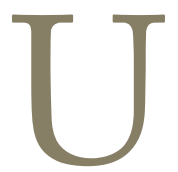

sable science for rangeland water resources recognizes water as an essential resource and a primary driver supporting processes and enterprises on rangelands. "Water is essential for life" means one thing to an urban homeowner facing outdoor water-use restrictions like limits to landscape watering during drought and another thing to a rancher whose pastures have produced little or no forage. The urban homeowner risks loss of investment in landscape plants that die during drought, whereas the rancher might lose a significant portion of the family ranch when the cow herd is liquidated in a depressed market. These nuances to the meaning of "water security" reflect the formidable challenges to providing the nation's water security. They are exacerbated by conversion of rangeland to less water-friendly land uses, increased temperature and decreased precipitation accompanying climate change, and increasing competition for water among both consumptive and nonconsumptive water uses. It follows that the challenge for rangeland professionals, including research scientists, is accurately predicting the consequences to water of land-use change, climate change, and increasing competition for water while also providing socially acceptable sciencebased solutions. The good news for rangeland professionals and research scientists is that because water is indeed essential for life, our knowledge and skills will be essential for addressing these issues. The caveat for relevance of our science and professional know-how is that we produce usable science and appropriately transfer the science to managers.

Water scarcity, degraded water quality, and inadequate sanitation negatively impact food security, livelihood choices, and educational opportunities for lower income families around the globe. Throughout the last century, water use grew at more than twice the rate of population increase, and although there is yet no global water scarcity, regions of every continent are chronically short of water. ${ }^{1}$ Nearly one-fifth of the world's population (1.2 billion) lives in areas of physical scarcity, and 500 million people are approaching this situation. Another 1.6 billion people, or almost one-quarter of the world's population, face economic water shortage (little or no capacity to transport water). ${ }^{2}$

\section{Why Rangeland Water is Highly Valued and Vulnerable}

Why should water be at the top of everyone's agenda including the community of nations, the United States, and the Society for Range Management? Water tops most people's list of concerns because they understand their reliance on water and recognize their vulnerability to an inadequate supply of high quality water. Many Americans (55-60\%) surveyed in Gallup's 2014-2015 Environment Poll say they worry about contamination of soil and water by toxic waste, pollution of rivers, lakes, and reservoirs, pollution of drinking water, and the maintenance of the nation's supply of fresh water. ${ }^{3}$ By contrast, fewer than $32 \%$ were concerned specifically with global climate change. ${ }^{3,4}$ Therefore, in this section, we provide a backdrop specific to the value and vulnerability of rangeland water.

\section{Conversion of Rangelands}

Rangelands function as high quality watersheds that produce abundant, clean water, but conversion of rangeland 
to other land uses continues to outpace other land-use conversions in the United States and threatens the nation's water security. For example, grassland habitats on rangelands in California's Central Valley and surrounding foothills might decline by $37 \%$ by 2100 from land-use and climate change. Discussions about the future of usable water science on rangelands predicted that ecosystem services including water would continue to face increasing pressure and competition. These services are strongly affected by the quantity of water delivered to rangelands and water partitioning among evapotranspiration (ET), ground water recharge, and surface water flow. ${ }^{5}$ Many relatively static factors (topography, soils, and geology) and dynamic factors (climate, land management, and land use) interact to determine how this water is partitioned and how it will be delivered to competing consumers. ${ }^{6}$ Increasingly, landscape change could adversely affect the water balance and water available to support rangeland processes. Quantifying rangeland water availability both in situ and for off-site use - the water budget - requires understanding across multiple spatial scales and over long time periods. ${ }^{6-9}$

\section{Groundwater, Irrigation, and Food Security}

Still valued for livestock grazing, rangelands are valued increasingly for capture of surface and subsurface water leading to storage. ${ }^{10}$ In the western United States, groundwater is the dominant form of water provision for the two major water uses, irrigation and municipal water supply. ${ }^{11}$ Rangelands cover about $31 \%$ or 308 million ha of the United States, ${ }^{6}$ and are the largest land cover by area in the western 17 states. Habitat loss, combined with urbanization and extended periods of drought, can reduce groundwater recharge, especially on deep soils. The implications of depleted aquifers that undermine water security for municipal water supply, industry, and irrigated agriculture are immense. Groundwater depletion has increased markedly since 1950 with the maximum rates since $2000 .^{12}$ Sixteen of the 17 western rangeland states contain many of the most depleted aquifers in the United States (Fig. 1).

Conversion of rangelands might reduce aquifer recharge. Applying six spatially explicit climate/land-use change scenarios for the Central Valley of California and surrounding foothills, Byrd et al. ${ }^{5}$ predicted that up to $37 \%$ of the region's rangelands would be lost by $2100 .{ }^{5}$ Future land use change through urban development would reduce the value of precipitation for recharge, particularly on deep soils. Their results support the need for climate-smart land-use planning that takes recharge areas into account to ensure the possibility of water storage in dry years. Agricultural expansion also is predicted to reduce rangelands, although Byrd et al. suggest that more modeling is needed on feedbacks between agricultural expansion on rangelands and water supply.

\section{Water for Energy}

Energy exploration and development in the United States require water, and energy is required for water supply, creating what has been called the energy-water nexus. ${ }^{13}$ US water consumption by 2030 will increase by $7 \%$ above the level consumed in 2005; $85 \%$ of this growth is attributed to the energy sector including biofuels. ${ }^{14}$ Based on examining data
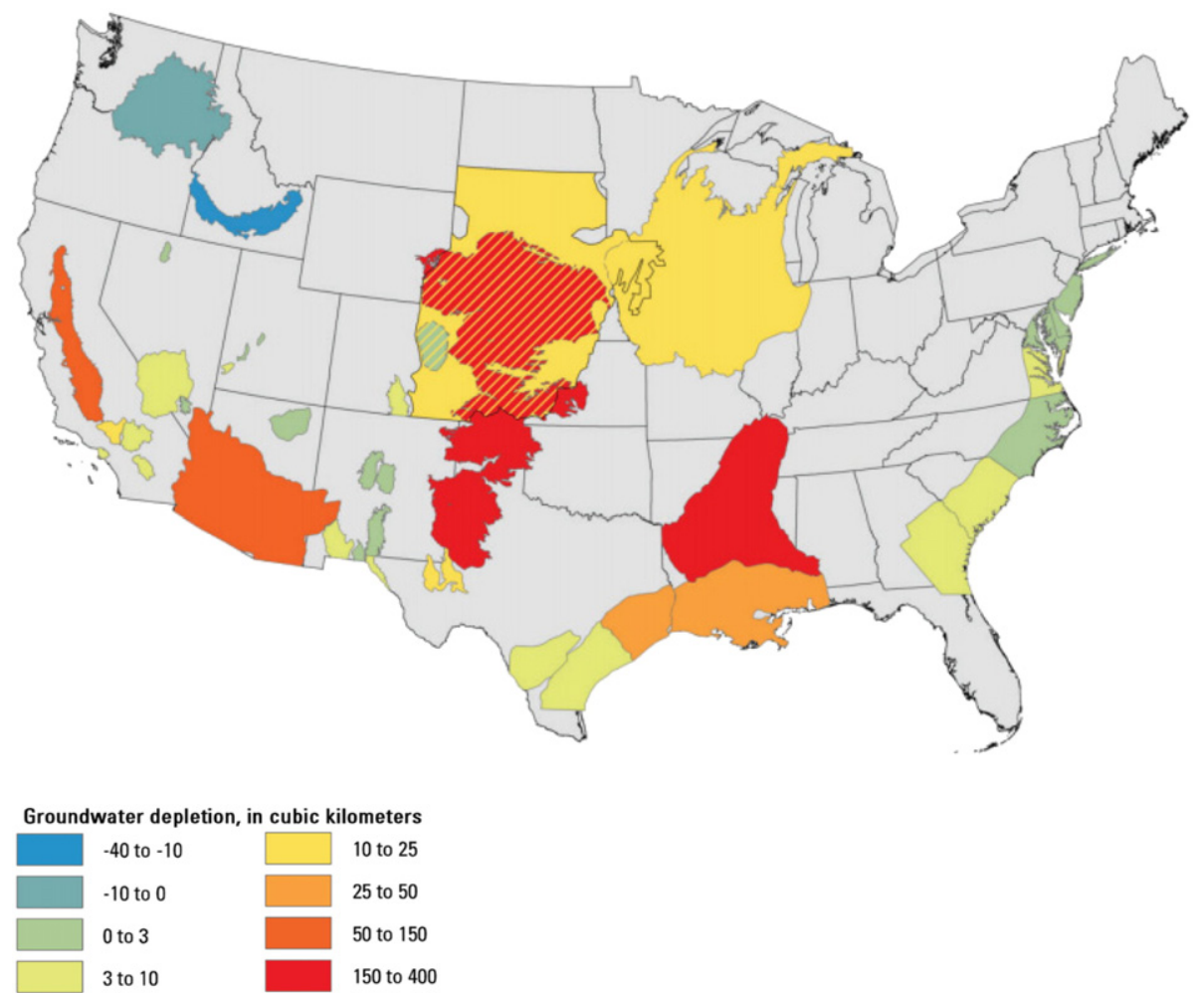

Figure 1. Map of the lower 48 states of the United States showing cumulative groundwater depletion from 1900 to 2008 in 40 aquifer systems or subareas. ${ }^{12}$ Hatching in the Dakota aquifer is to denote overlap with other aquifers with different depletion values. 
from the recent record drought in the Southern Great Plains, electrical power generation is comparatively better situated in the more semiarid western states than humid eastern United States. ${ }^{15}$ However, reservoir levels are threatened during prolonged drought, for example, reservoir storage for power plant cooling declined by $30 \%$ in Texas in the 2011 drought. ${ }^{16}$ The western rangeland states may find that using less water for energy in the future overrides concerns about carbon emissions from conventional power generation including coal-fire electrical generation. ${ }^{13}$

\section{Drought Threatens Sustainability of Ecosystem Services from Rangeland}

Coping with drought on rangelands involves preparedness, proactive management practices, and policies that are flexible, permitting drought adaptation. Ongoing drought causes undesirable effects on rangelands-alteration of plant cover and accelerated erosion, animal productivity, ecosystem service provisioning, and community sustainability. ${ }^{17}$ Rangelands that support livestock grazing often are highly susceptible to risk; because forage production is tied to precipitation, suffering along with other agricultural producers both intra- and interannual variability that makes proactive planning difficult. Prolonged drought and the associated precipitation variability often force reduction in livestock numbers, reduction in per-head productivity, and restrictions to pasture irrigation, which is important to providing forage outside of the growing season.

Once in a drought, some rangeland producers reduce animal numbers and sell all at nearly the same time resulting in falling livestock prices. With these lower prices, other producers lack the incentive to sell stock, grazing retained stock to the level of potential ecological damage. ${ }^{18}$ Kachergis et al. ${ }^{17}$ showed that large ranch size with a sufficient resource base, flexible operation characteristics, shorter grazing periods, and income diversification independent of drought-related production could reduce some drought impacts on Wyoming ranches. They speculated that increased flexibility in drought management may lead to healthier and more productive rangeland ecosystems and more resilient ranching operations by better synchronizing the balance between forage demand and supply.

\section{Rangeland Watersheds and Basins Matter to People}

Intimately linked to rangeland water issues are waterproducing landscapes or watersheds, areas that drain to a common outlet. Often the planning unit used when crafting management or development strategies is based on political geography or is targeted at enhancing production of a specific commodity with these activities falling short of their potential due to a variety of environmental and socioeconomic factors. Drainage patterns make the watershed a logical, natural hierarchical unit for rangeland planning and management. Degradation of watersheds in recent decades has brought long-term reduction of the quantity and quality of land and water resources, as shown in the case of cheatgrass-infested watersheds of the Great Basin. Changes in watersheds result from a range of natural and anthropogenic factors, including natural soil erosion, farming systems, nonsustainable extraction of water, mismanagement of grazing, deforestation, severe fire, and pollution. Energy and nutrient flow patterns internalize many of the costs and benefits associated with activities within the watershed. ${ }^{19}$ The combination of environmental costs and socioeconomic impacts has prompted investment in watershed management in many parts of the United States, but by some indicators, return-on-investment has been negligible while impairment of quality of the nation's water resources has continued. ${ }^{20}$

Watershed management is the integrated use of land, vegetation, and water in a geographically discrete drainage area for the benefit of its residents, with the objective of protecting or conserving the hydrologic and ecologic services that the watershed provides while reducing or avoiding negative downstream or groundwater impacts. Watershed management approaches require linking benefits and costs between upland and lowland sites, or it may be difficult to convince rangeland owners or local communities to change their current behavior. Rangeland watershed management needs to be adapted to the local situation and to changes in natural resource use and climate; within a watershed context, management is enabled by combining anthropocentric considerations with biophysical realities.

Rangelands, managed through the application of ecological rather than agronomic principles, compose a significant portion of the nation's watersheds. Water that ends up in rivers, lakes, groundwater, and coastal waters downstream may fall first on rangelands. Maintaining availability of water from rangeland watersheds depends on conservation and stewardship that may involve federal, state, tribal, and local governments, the public, and the private sector to restore and sustain watershed health. Unpredictable intra- and interannual precipitation are common to all rangelands from California's Mediterranean climate-dominated annual grasslands and oak savannahs ${ }^{21,22}$ to Texas's continental- and gulf coast-dominated mixed brush. ${ }^{23}$ Climate change projections indicate that precipitation uncertainty for rangelands is likely to increase. ${ }^{24,25}$ Despite this uncertainty, rangelands serve a critical role supplying water for a variety of uses. The provision of water has been called "the ecosystem service that most directly links growing human populations to rangelands." ${ }^{6}$ Therefore, a rich suite of pressing research opportunities exists to produce usable science related to water on rangelands.

\section{Workshop Process for Evaluating Usable Science for Water}

The workshop's water working group was composed of representatives of the rangeland beef cattle industry, three comprehensive research universities, a national program leader in USDA-NIFA, and a nonprofit conservation organization focused on water (see Maczko et al. of this issue for the details of the Workshop on Future Directions for Usable Science for Rangeland Sustainability). The goal of the workshop was to develop a broad research agenda intended to address the need for usable science pertaining to rangelands. Our group was 
one of the smaller constituent working groups reporting in this issue.

The water working group first brainstormed a list of issues that we believed to be most important to water, placing no specific bounds on the topics other than that they relate to rangelands of the United States. Issues we identified were combined with those of the other working groups to yield a total of 142 issues, which were evaluated and ranked by the entire workshop group. Because water integrates many issues, we anticipated that several of our water issues would be common to all working groups, and this was borne out by ranks assigned by the larger group with four of the top six issues related to water. Transfer of knowledge to land managers, drought preparedness (a combination of two issues-proactive drought planning and forward-looking drought predictors), and proactive watershed management were the three water issues ranked at the top by the larger group. After the water working group further discussed these priorities and identified researchable questions, we presented our ideas to the entire workshop group and entertained feedback in an open discussion session. During this informative and lively discussion session, a fourth issue- - how to productively move from cropland to rangeland-rose to prominence as an essential rangeland water-related issue ranked relatively low by workshop participants. These four issues and insights into directions for producing usable science to address them are described below.

\section{Directions for Research in Rangeland Water}

Extending science and BMPs to users through Extension is a fundamental bottleneck to transferring science to rangeland water and watershed management. These issues, "transfer of knowledge to land managers" and "increase support of rangeland programs and extension," were ranked No. 2 and No. 4, respectively, by workshop participants in overall importance toward delivering usable science for rangelands. Translating science involves inspiration, discovery, integration, dissemination, and application. Managing rangeland watersheds requires understanding complex interactions between socioeconomic and biophysical forces. Recent insights from social science, including rangeland social science research, indicate that stakeholder involvement at all stages of the research, education, and extension process (e.g., the concept of co-production) is essential to effectively translate science. Cultivating an awareness of the human and biophysical linkages within a rangeland watershed is crucial to developing foundational support necessary to achieving sustainable water use and management. Critical activities on rangeland watersheds happen in remote areas, distanced from the political and financial hubs vital to providing support. Having a low profile due to location is exacerbated by low profile benefits produced by best management practices (BMPs). Vegetation cover, for example, provides striking benefits to conserving soil on hilly rangelands, but the benefit is difficult to assess and explain. The challenge is to acquire public/policy support for BMPs that focus on preventing potential degradation for activities that promise to provide benefits at spatial and temporal scales that evade assessment by methods ordinarily employed by agencies. Degradation prevented should be a coincident, but is usually less attractive to decision makers more focused on highly visible ways to stimulate local or national job creation and economies. A partial solution to this dilemma is public behavior and perception change realized by vigorous Extension, which is predicated on public support and public funding. Solving this conundrum represents perhaps the most important, yet the most formidable goal, within the arena of usable science.

Drought preparedness - a combination of two issues addressing drought preparedness, proactive drought planning and forward-looking drought predictors - tied for rank No. 3 by workshop participants. Key to reducing drought impacts on the production of goods and ecosystem services from rangelands and realizing drought preparedness (e.g., knowing the impact of drought on the various sectors of water use; defining the sources of drought vulnerability for water use sectors and outline monitoring programs to alert water users and resource managers of the onset and severity of drought events; and the preparation of drought response options and drought mitigation strategies to reduce the impact of drought to water users on rangelands) is the recognition of threshold indicator values that tie levels of drought severity with appropriate responses to sustain production. These indicators or triggers often are used to make decisions about water use, redistribution, drought aid, and eligibility. Therefore, sustainable production under highly variable moisture conditions requires readily understandable, scientifically sound drought triggers at appropriate temporal and spatial scales and specific to local rangeland systems and conditions. Although advances in the science behind the most appropriate drought triggers exists, still needed is enhanced understanding of the connection between trigger levels and predictions of drought and drought management responses.

Advances in monitoring technology, drought prediction, and decision support tools are rapidly progressing. For example, in an effort funded by USDA-NIFA, a team of scientists and educators from Texas A\&M University, Purdue University, and North Carolina State University are developing a high-resolution drought trigger tool for the United States with the goal of putting detailed drought information into the hands of every farmer and rancher, with that information tailored to common decision points and regional needs. The team continues to develop drought-monitoring products by taking high-resolution precipitation analyses produced by the National Weather Service every day and converting them into drought indices. Using archives of past climate and high-resolution analyses of current climate to accomplish this task, these scientists and educators develop publications and workshops to make sure that the agricultural community understands the applications and limitations of their drought products for applications to drought triggers and decision-making. Other studies by Purdue focused on cropland watersheds provide a range of expected values of hydroclimatic precursors that herald different classes of hydrologic droughts, observing that drought triggers are 
watershed specific. Among the hydroclimatic variables, soil moisture, precipitation, and runoff showed the greatest potential for assessing different classes of droughts. Drought triggers leading to drought preparedness for rangeland watersheds still need to be developed. One of the more promising new developments is an early warning system for "flash drought." It produces a rapid change index (RCI) developed from drought indices depicting anomalies in evapotranspiration, precipitation, and soil moisture. ${ }^{26}$ Similar tools are desperately needed in the western states; the RCI is reliable mostly for the central and eastern states.

Usable science for drought on rangelands also should include exploring the linkages between rangeland drought management practices and ecosystem health, improved ecological monitoring, and technology adoption behavior. Other proactive steps discussed by the water working group involved 1) encouraging forage-sharing, 2) promoting income diversification, and 3) diversifying from a cow/calf operation to both cow/calf and yearlings among other strategies. Future droughts may be longer and more intense; improving drought preparedness would help retain the provisioning of ecosystem goods and services. One participant specifically noted that provision of surface water is a key aspect of drought preparedness that deserves research attention.

Proactive watershed management to prevent degradation of high quality rangelands was ranked No. 5 by workshop participants. A variety of policies impose obstacles to appropriate management of a rangeland watershed. Wellvegetated, high quality rangeland and stable riparian areas provide tangible economic benefit produced from wildlife, livestock, and timber. As rangelands degrade, a paradox of increasing economic prosperity from resource exploitation can occur concomitantly with declining environmental health. At some point during rangeland degradation, provision of ecosystem services such as clean water and flood management will collapse, resulting in societal costs far exceeding benefits from resource exploitation (Fig. 2). Using a well-known example, the overall cost of sedimentation of world reservoirs was evaluated between US $\$ 15$ and US $\$ 20$ B per year, i.e., $30 \%$ of the overall annual maintenance plus management expenses of $\$ 60 \mathrm{~B}$ for dams or $10 \%$ of the $\$ 200 \mathrm{~B}$ annual dam benefits. ${ }^{27}$ In the United States, $\$ 6$ B per year is lost from potential irrigation and hydroelectricity due to dam sedimentation, and $\$ 520 \mathrm{M}$ is required each year to dredge waterways for transportation. ${ }^{28}$ Yet, the value of rangeland watersheds for erosion prevention is often not reflected in commodity prices due to our inability to completely quantify the loss or monetize the value. Better ecosystem service valuation procedures, still a real research need, are required to assist managers, planners, and policy makers to understand that inherent soil, topography, or climatic restrictions limit rangeland suitability for intensive use, cropland conversion, or urban development. Some rangelands also will have critical functions within the watershed such that conversion to other use might result in downstream threats, such as disrupting the supply of fresh water and elevating flood or erosion risk. Adopting a watershed perspective focuses decision makers, planners, and managers toward expending funds to protect one part of the watershed to benefit activities in another portion.

Technologies to restore abandoned cropland back to productive rangeland, driven by aquifer depletion, drought, and climate change. This issue was ranked initially in a seven-way tie as No. 20 by workshop participants but highly ranked for relevancy and difficulty by the water working group. Significant amounts of irrigated cropland in aquifer overdraft areas will revert to dryland in future years. Because of its large size and severity of overdraft, particularly in the southern portion and the recent southwestern US drought, the Ogallala Aquifer area is the focus of considerable attention and makes sense as a case study. After the Dust Bowl of the "Dirty "30s" and before World War II, land in the High Plains was primarily rangeland used for producing cattle with some

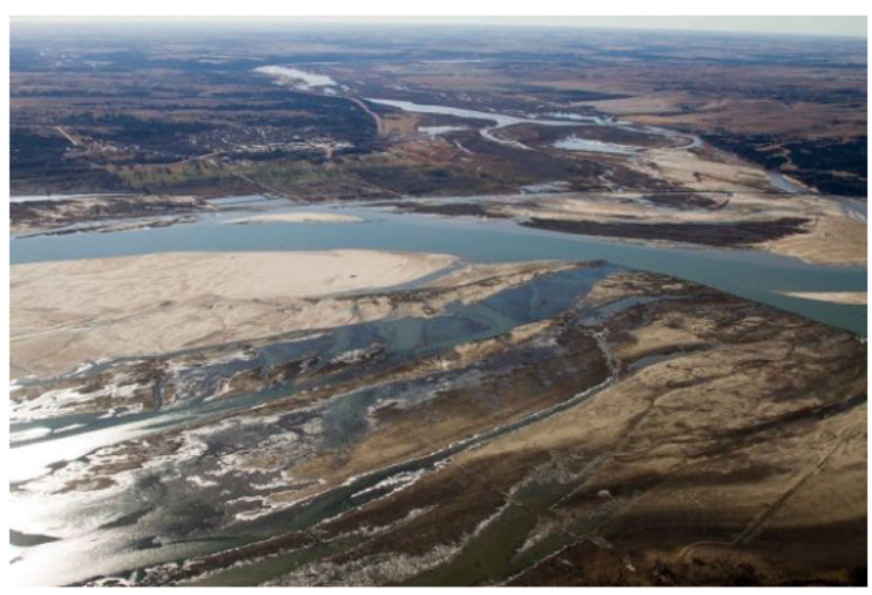

Figure 2. The key characteristics of a watershed that drive management approaches are the integration of land and water resources, the causal link between upstream land and water use and downstream impacts and externalities (e.g., serial externalities, the actions of the upland inhabitants affect the downstream inhabitants but the actions of downstream inhabitants cannot impact those upstream), and the multiplicity of stakeholders. This photo, taken 28 November 2011, shows the confluence of the Niobrara and Missouri rivers near Niobrara, Nebraska. The Niobrara River contributes $50 \%$ of the sediment entering Lewis and Clark Lake (courtesy Nick Hytrek nhytrek@siouxcityjournal.com). 


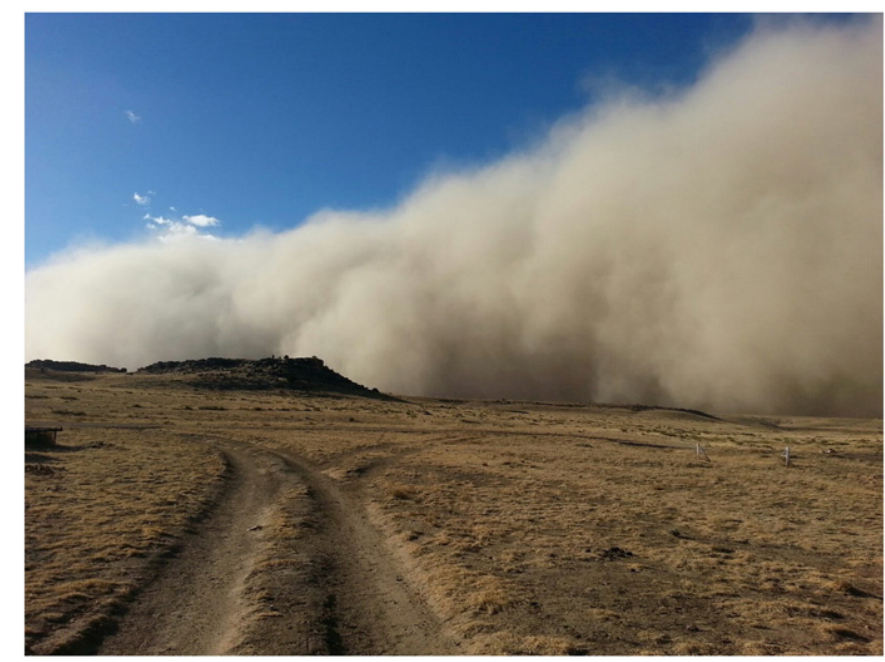

Figure 3. Dust storm in Cimarron County, Oklahoma, January 2013. Wind erosion from fallow crop fields and fields with failed winter wheat in southeastern Colorado are the source of the dust clouds (photo courtesy of Chad Love, http://mallardofdiscontent.blogspot.com/2014/01/then-and-now.html). Stabilizing soil and restoring perennial vegetation in this and other areas of the West after aquifer depletion serve as major research and extension needs.

dryland crops. Irrigation expanded rapidly after the war and especially during the drought of 1951-1956. High quality water of "unlimited" supply combined with fertile soil, newly developed crops, and a favorable climate led to agricultural production expansion, accounting for more than $25 \%$ of all irrigated land in the United States. In 1976, Congress recognized the Ogallala as a "mined" source of irrigation water with restricted recharge potential and established the six-state High Plains Study to assess the present and future status of the aquifer. ${ }^{29}$ Results of the study projected that Kansas and Texas would show significant declines in irrigated agriculture and simultaneous dryland farming increases. Dryland acreage in Kansas would increase more than irrigated acreage would decrease, indicating that increase in cropland would come from rangeland with higher erosion potential. This conversion would occur as a result of declining water supply or pumping costs, or a combination of the two. If water availability was the principal constraint, conversion would be gradual, moving from fully-irrigated to limited-irrigated to dryland. According to Engelbert and Scheuring, ${ }^{29}$ orderly conversion to dryland presented little environmental hazard. By contrast, of greater concern was sudden abandonment in which energy cost exceeded the value of the crop. Center-pivot irrigation systems on the most environmentally sensitive lands that were taken out of rangeland due to economic incentives will have limited dryland production potential as center-pivots are abandoned. Beginning in 1985, in some parts of the Ogallala, irrigation pumping costs exceeded crop value and farmers began to abandon farmland. Unless technology and an orderly plan is developed to restore these center pivot lands with productive, perennial rangeland plants, severe wind erosion of the predominantly sandy soil could result. According to Steward et al. ${ }^{30} 97 \%$ of predevelopment groundwater storage was untapped in 1960 , but by 2010 , only $70 \%$ remained, with a declining trend modeled to continue through 2110 and beyond. Significant expansion of irrigated acreage occurred on marginal land prone to accelerated wind erosion (Fig. 3). Restoration of these former rangelands lands will require new technology or resurrecting technology not used since the soil bank, unless it is accomplished before irrigation is curtailed, which is unlikely. Research issues related to the Ogallala case study include economic evaluation, particularly cost-benefit analysis, of rangeland restoration after cropland abandonment. The same issues relate to other declining aquifers in the West (Fig. 1).

In conclusion, the rangeland water working group identified important rangeland water issues that workshop participants confirmed as high priority needs for usable science. Discussion within the working group and with the larger workshop participant group highlighted perspectives about each issue, particularly knowledge gaps in usable science and transfer of usable science, which we included in this paper. These issues present significant challenges for rangeland professionals, including research scientists, because effectively addressing these issues will require change in the nation's research and Extension model. Constructing and applying new models for prioritizing research and for translating science to managers and policy makers are chief among these changes.

\section{References}

1. WWaP (World Water Assessment Programme), 2012. The United Nations World Water Development Report 4: Managing Water under Uncertainty and Risk. Paris, France: UNESCO.

2. Water and Sustainable Development: From Vision to Action, UN-Water Annual International Zaragoza Conference; 15-17 January 2015. Available at: http://www.un.org/ waterforlifedecade/waterandsustainabledevelopment2015/ water_resources_management.shtml Accessed 22 December 2015.

3. GALLUP, 2015. Environmental Poll. Available at: http:// www.gallup.com/poll/182105/concern-environmental-threatseases.aspx Accessed 22 December 2015. 
4. O’Neill, M.P., AND J.P. Dobrowolski. 2011. Water and agriculture in a changing climate. Horticultural Science 46:155-157.

5. Byrd, K.B., L.E. Flint, A. Pelayo, C.F. Casey, B.M. Sleeter, C.E. Soulard, A.L. Flint, and T.L. Sohl. 2015. Integrated climate and land use change scenarios for California rangeland ecosystem services: wildlife habitat, soil carbon, and water supply. Landscape Ecology 30:729-750.

6. Havstad, K.M., D.P.C. Peters, R.J. Skaggs, J.R. Brown, B. Bestelmeyer, E. Fredrickson, J. Herrick, and J. Wright. 2007. Ecological services to and from rangelands of the United States. Ecological Economics 64:261-268.

7. Scanlon, B.R., D.G. Levitt, R.C. Reedy, K.E. Keese, and M.J. SulLy. 2005. Ecological controls on water-cycle response to climate variability in deserts. Proceedings of the National Academy of Sciences 17:6033-6038.

8. Brown, J., ANd N. Macleod. 2011. A site-based approach to delivering rangeland ecosystem services. Rangelands 33:99-108.

9. He, M., AND T.S. Hogue. 2012. Integrating hydrologic modeling and land use projections for evaluation of hydrologic response and regional water supply impacts in semi-arid environments. Environmental Earth Sciences 65:1671-1685.

10. Yahdjian, L., O.E. Sala, and K.M. Havstad. 2015. Rangeland ecosystem services: shifting focus from supply to reconciling supply and demand. Frontiers in Ecology and the Environment 13:45-51.

11. Richey, A.S., B.F. Thomas, M.-H. Lo, J.S. Famiglietti, S. Swenson, AND M. Rodell. 2015. Uncertainty in global groundwater storage estimates in a Total Groundwater Stress framework. Water Resources Research 51:5198-5216.

12. KoniKow, L.F. 2013. Groundwater depletion in the United States (1900-2008). Reston, Virginia, USA: U.S. Geological Survey. Scientific Investigations Report 20133-5079.

13. Scott, C.A., S.A. Pierce, M.J. Paseualetti, A.L. Jones, B.E. Montz, And J.H. Hoover. 2011. Policy and institutional dimensions of the water-energy nexus. Energy Policy 39:6622-6630.

14. Copeland, C. 2014. Energy-water nexus: the water sector's energy use. Congressional Research Service Report :7-5700.

15. Ackerman, F., And J. Fisher. 2013. Is there a water-energy nexus in electricity generation? Long-term scenarios for the western United States. Energy Policy 59:235-241.

16. Scanlon, B.R., I. Duncan, and R.C. Reedy. 2013. Drought and the water-energy nexus in Texas. Environmental Research Letters 8:045033.

17. Kachergis, E., J.D. Derner, B.B. Cutts, L.M. Roche, V.T. Eviner, M.N. LubELL, AND K.W. TATE. 2014. Increasing flexibility in rangeland management during drought. Ecosphere 5:77.

18. Stafford Smith, D.M., G.M. Mckeon, I.W. Watson, B.K. Henry, G.S. Stone, W.B. Hall, and S.M. Howden. 2007. Learning from episodes of degradation and recovery in variable Australian rangelands. Proceedings of the National Academy of Sciences 104:20690-20695.

19. Dobrowolski, J.P., And T.L. Thurow. 1995. A practical rationale for implementing effective watershed-scale development: the EPIO Approach. In: \& WEST NE, editor. Rangelands in a Sustainable Biosphere. Denver: Society for Range Management. p. $170-172$.
20. Mississippi River/Gulf of Mexico Watershed Nutrient TASK Force, 2004. A science strategy to support management decisions related to hypoxia in the Northern Gulf of Mexico and excess nutrients in the Mississippi River Basin: prepared by the Monitoring, Modeling, and Research Workgroup of the Mississippi River/Gulf of Mexico Watershed Nutrient Task Force. U.S. Geological Survey Circular 1270. 58 pp.

21. Merenlender, A., M. Deitch, and S. Feirer. 2008. Decision support tool seeks to aid stream-flow recovery and enhance water security. California Agriculture 62:148-155.

22. Ash, A., P. Thornton, C. Stokes, and C. Togtohyn. 2012. Is proactive adaptation to climate change necessary in grazed rangelands? Rangeland Ecology \& Management 65:563-568.

23. Brown, J.R., AND S.R. Archer. 1999. Shrub invasion of grassland: recruitment is continuous and not regulated by herbaceous biomass or density. Ecology 80:2385-2396.

24. Shaw, M.R., L. Pendleton, D.R. Cameron, B. Morris, D. Bachelet, K. Klausmeyer, J. Mackenzie, D.R. Conklin, G.N. Bratman, J. Lenihan, E. Haunreiter, C. Daly, and P.R. Roehrdanz. 2009. The impact of climate change on California's ecosystem services. California Energy Commission. Scenarios Report. CEC-500-2009-025-D.

25. Shaw, M.R., L. Pendleton, D.R. Cameron, B. Morris, D. Bachelet, K. Klausmeyer, J. Mackenzie, D.R. Conklin, G.N. Bratman, J. Lenihan, E. Haunreiter, C. Daly, and P.R. Roehrdanz. 2011. The impact of climate change on California's ecosystem services. Climatic Change 109:465-484.

26. Otkin, J.A., M.C. Anderson, C. Hain, and M. Svoboda. 2015. Temporal changes in drought indices to generate probabilistic drought intensification forecasts. Journal of Hydrometeorology 16:88-105.

27. HydraCoop, 2013. Dams with significant siltation problems. Available at: http://www.hydrocoop.org/dams-with-significantsiltation-problems Accessed 22 December 2015.

28. Pimentel, D., C. Harvey, P. Resosudarmo, K. Sinclair, D. Kurtz, M. Mcnair, S. Crist, L. Shpritz, L. Fitton, R. SAFFOURI, AND R. BLAIR. 1995. Environmental and economic costs of soil erosion and conservation benefits. Science 267:1117-1123.

29. Engelbert EA, \& Scheuring AF, editors. Water scarcity: Impacts on western agriculture. Berkeley: Univer. Berkeley: Calif. Press. 500 pp.

30. Steward, D.R., P.J. Bruss, X. Yang, S.A. Staggenborg, S.M. Welch, and M.D. Apley. 2013. Tapping unsustainable groundwater stores for agricultural production in the High Plains Aquifer of Kansas, projections to 2110. Proceedings National Academy of Science 110:E3477-E3486.

Authors are National Program Leader, Rangeland and Grassland Ecosystems, Agriculture Water Security, USDA-NIFA, 1400 Independence Ave SW, Washington, DC 20250, USA, jdobrowolski@nifa.usda.gov (Dobrowolski); and Regents Professor, Department of Natural Resource Ecology and Management, Oklahoma State University, Stillwater, Oklahoma 74078, USA (Engle). 